Cornell University Law School Scholarship@Cornell Law: A Digital Repository

$8-20-2015$

\title{
Possible Futures for the Legal Treatise in an Environment of Wikis, Blogs, and Myriad Online Primary Law Sources
}

Peter W. Martin

Cornell Law School, pm552@cornell.edu

Follow this and additional works at: http://scholarship.law.cornell.edu/clsops_papers

Part of the Legal Writing and Research Commons, and the Scholarly Publishing Commons

\section{Recommended Citation}

Martin, Peter W., "Possible Futures for the Legal Treatise in an Environment of Wikis, Blogs, and Myriad Online Primary Law Sources" (2015). Cornell Law Faculty Working Papers. Paper 120.

http://scholarship.law.cornell.edu/clsops_papers/120 


\title{
Possible Futures for the Legal Treatise in an Environment of Wikis, Blogs, and Myriad Online Primary Law Sources
}

\begin{abstract}
Peter W. Martin ${ }^{\dagger}$
Major law publishers have begun producing ebook versions of some of the legal treatises they own. Despite asserted advantages over both print and online versions of the same content, these represent a step back from what treatises have become within the major online services and even further from what they might become now that numerous sources of primary law are directly accessible via the Internet.

The article traces the corporate and technological developments that have placed existing treatises in their present posture. Drawing upon the author's own work preparing a legal treatise designed for digital rather print delivery, it reviews a range of possible futures for this classic form of legal scholarship.

The article argues (1) that electronic treatises that have been cut loose from print norms can offer major advantages in format and function over print treatises that have simply been ported to Westlaw, Lexis, or one of their competitors and (2) that strong reasons exist for treatise authors and those with a stake in their work to prefer publication on the open Web to inclusion in one of the large proprietary systems. It concludes with a description of Web-based utilities that might enable such treatises to be competitive with those held in the major online systems and with speculation about the institutional arrangements that might enable treatise-like works delivered in electronic format to survive and even thrive without being confined to a single comprehensive database.
\end{abstract}

\footnotetext{
* (C) Peter W. Martin, 2015. This work is licensed under the Creative Commons AttributionNoncommercial-ShareAlike 3.0 License. To view a copy of this license, visit http://creativecommons.org/licenses/by-nc-sa/3.0/. The article builds on papers presented at the Law via the Internet Conference, Montreal, 2007 and at faculty workshops in 2011.

† Jane M.G. Foster Professor of Law, Emeritus, Cornell Law School, Ithaca, New York, and cofounder, Legal Information Institute, Cornell.
} 


\section{The Appearance of Law Ebooks}

Recently Thomson Reuters and LexisNexis began releasing ebook versions of some of their treatises and other legal reference works, in the U.S. and elsewhere. ${ }^{1}$ Wolters Kluwer has followed suit, publishing numbers of its Aspen imprint law titles in ebook form. ${ }^{2}$ Bloomberg BNA appears headed in the same direction. ${ }^{3}$

While the distribution strategies of these companies differ, the marketing materials of all four highlight a similar list of asserted advantages of this new electronic format over print, on the one hand, and online access to treatise-length commentary, on the other. Having works in ebook form, it is argued, allows one: 1) to carry around many volumes' worth of material on a phone, tablet, or laptop, 2) to search a book's contents, 3) to move directly along its internal cross-references, and 4) with an Internet connection and subscription, to follow its citations of primary legal sources into the publisher's online system. ${ }^{4}$ However, unlike books held within Westlaw, Lexis, LoisLaw, or Bloomberg Law, ${ }^{5}$ once loaded on a portable device, these do not require Internet access for use. The lawyer or other legal researcher can consult an ebook anywhere. Not stressed but also true, is that these ebooks don't require a subscription to the publisher's database. A lawyer who relies on Westlaw, Fastcase, or Google Scholar for her case research can, nonetheless, use Nimmer on Copyright published by LexisNexis or Aspen's Epstein on Intellectual Property. While she can't follow the Nimmer citation links into Lexis or the Epstein links into LoisLaw, she can insert them into a browser aimed at the online service of her choice. Lastly, the software platforms employed by all four publishers enable readers to personalize their ebooks with project-specific notes, tags, and bookmarks. ${ }^{6}$ For all of that, these remain, at core, minimally enhanced books, tied down by the print form for which they were originally prepared even more than their online counterparts. As a result, they fall short of what a commentary work of treatise-like scope might be in

\footnotetext{
${ }^{1}$ See Michael Cohn, Thomson Reuters Builds eBook Library, ACCOUnTING TODAY, July 10, 2012, 2012 WLNR 14356219. Most, although not all, of these ebooks are clones of works also available in print. For an exception see Kenneth A. AdAms, The Structure Of M \& A CONTRACTS (2011), http://legalsolutions.thomsonreuters.com/law-products/Other/The-Structure-Of-M--AContracts/p/100081985?s_tnt=170897:0:0 (last visited Aug. 17, 2015).

${ }^{2}$ See WK eReader, https://itunes.apple.com/us/app/wk-ereader/id546756775?mt=8 (last visited Aug. 17, 2015).

${ }^{3}$ See Bloomberg BNA, http://www.bna.com/reductions-force-employment-p17179877052/ (last visited Aug. 17, 2015).

${ }^{4}$ See Barbara Cookson, SOLO IP Blog May 30, 2015, http://soloip.blogspot.co.uk/2015/05/legal-e-booksgo-proview.html.

${ }^{5}$ Rather than follow the vendors' shifting names for their services, classic and next generation, this article will refer to them by their historic names throughout.

${ }^{6}$ See Thomson Reuters, Law eBooks on ProView, http://legalsolutions.thomsonreuters.com/lawproducts/law-books/proview-ebooks (last visited Aug. 17, 2015); LexisNexis eBooks, http://www.lexisnexis.com/ebooks/lending/ (last visited Aug. 17, 2015); WK eReader, http://itunes.apple.com/us/app/wk-ereader/id546756775?mt=8 (last visited Aug. 17, 2015); Bloomberg BNA, http://www.bna.com/reductions-force-employment-p17179877052/ (last visited Aug. 17, 2015).
} 
the present legal research environment. Not clear is whether it is in the interest of their publishers to transform them into anything more.

How the expert law treatise has evolved in the digital era has been as much a story of ownership and commercially grounded choice among competing revenue streams as of technology and fresh possibilities. This paper begins by tracing the several stages of that still unfolding story. It concludes with speculation about the institutional arrangements that might foster the creation and maintenance of treatises free of the limits imposed by print and of the incentives which lead the major legal publishers to tie them to their proprietary online services.

\section{Law Treatises at the Dawn of Computer-Based Legal Research}

While the earliest law treatises predate the systematic dissemination of court opinions, by the early twentieth century this form of legal commentary had become an essential tool for lawyers and judges seeking to organize and understand the growing quantity of published case law. That was a period of monumental treatises, books that brought order to large sectors of the common law and caused authors' names to become synonymous with their fields - evidence (Wigmore), contracts (Williston), trusts (Scott), and so on. Brian Simpson's history of the legal treatise, first published in 1981, documented the importance of those works but concluded that they marked a culmination. ${ }^{7}$ The title of his essay, "The Rise and Fall of the Legal Treatise,” summarized Simson's view of the status and future of the genre. Undoubtedly he was right to conclude that individual works of such dominance were not likely to be seen again. It is also true that even at the time Simson wrote other forms and outlets for scholarship were attracting more of the creative energy of U.S. legal academics. But empirically he was flat wrong. Law treatises proliferated during the latter half of the twentieth century. Many were summoned by new fields grounded upon statute rather than common law. ${ }^{8}$ The new titles did not necessarily supplant old ones. Existing treatises were sustained through successive editions. In time these became the responsibility, in whole or part, of second and third generation authors and revisers. Reference works of this type expanded in scope and detail. Because of their very number individual works and their authors grew

\footnotetext{
${ }^{7}$ A.W.B. Simpson, The Rise and Fall of the Legal Treatise: Legal Principles and the Forms of Legal Literature, 48 U. CHI. L. REV. 632 (1981). The essay was subsequently republished in a compilation of Simpson's historical writings. See A.W.B. Simpson, LEGAL THEORY AND LEGAL HistORY: EsSAYS ON THE COMMON LAW 275-319 (1987).

${ }^{8}$ Securities Regulation by Louis Loss first appeared in 1951. It grew into the 11-volume third edition (with Joel Seligman) published in 1989 by Little Brown \& Co. Boris I. Bittker's influential Federal Taxation of Income, Estates, and Gifts was first published in 1981; the second edition (with Lawrence Lokken), in 1989, publisher Warren Gorham \& Lamont. The first edition of Nimmer on Copyright, Melville B. Nimmer's major treatise in that field appeared in 1963, published by Matthew Bender \& Co. It has since 1985 been sustained and revised by his son David. See generally Ann Bartow, The Hegemony of the Copyright Treatise, 73 U. CINN. L. REV. 581 (2004).
} 
less conspicuous. In time most legal fields, from admiralty to zoning, were covered by multiple treatises marketed by the country's then still numerous law publishers. ${ }^{9}$

While coming in different sizes and formats, what distinguishes the legal treatise from other categories of commentary is that it aims to survey a complete field, providing organized, efficient, and relatively up-to-date access to the law on its many topics. Examples range from multi-volume works covering the uniform commercial code, bankruptcy, or copyright to stand-alone books on practice under the civil procedure rules of a particular state. Such works may advocate a distinct view, favor one line of authority over another, or present greater clarity or certainty on a point than current case law. Yet, in theory, no treatise holds authority independent of the statutes, regulations, and judicial opinions on which it is based. When written by a widely acknowledged and respected expert, lawyers and judges may, it is true, rely upon the legal analysis set out in a treatise without performing a comprehensive, independent review of the underlying primary law sources, or yield to its persuasion on a point to which such sources do not speak clearly. ${ }^{10}$ On the other hand when a treatise comes into direct conflict with statute or case authority there is little doubt about which ought to prevail. ${ }^{11}$

These are not books written to be read from cover to cover in the manner of a work of fiction, history, philosophy or even a student introduction to the field. Their principal intended use is by the lawyer or other legal adviser, judge or other decision-maker assessing a problem, confronting an unfamiliar, novel, or complex situation and needing a helpful starting point. ${ }^{12}$ Standing between the relevant primary authority and the legal professional, when they work as intended, treatises save time and improve the quality of legal analysis and decision-making in some of the following ways: ${ }^{13}$

- By providing overview good treatises assist the researcher in placing a particular issue or problem in broader context.

\footnotetext{
${ }^{9}$ Admiralty was covered by Grant Gilmore \& Charles L. Black, Jr., The Law of Admiralty (2d ed. Foundation Press 1975), Erastus C. Benedict, Kanught's Benedict on Admiralty (7th ed. Matthew Bender \& Co. 1950), and Theodore M. Etting, The Admiralty Jurisdiction in American (Littleton Co. 1986). Treatises on zoning law were more numerous. See infra pp. 7-8.

${ }^{10}$ See, e.g., In re Beaubouef, 966 F.2d 174, 178 (5 $5^{\text {th }}$ Cir. 1992) (quoting Collier on Bankruptcy); Kelley v. Chi. Park Dist., 635 F.3d 290, 303-04 (7 $7^{\text {th }}$ Cir. 2011) (quoting Nimmer on Copyright and Patry on Copyright). For an historical survey of judicial citation practice in England, see Alexandra Braun, Burying the Living? The Citation of Legal Writings in English Courts, 58 AM. J. CoMP. L. 27 (2010).

${ }^{11}$ See, e.g., King v. Ill. Nat'l Ins. Co., 2008-1491, pp. 14-15 (La. 04/03/09); 9 So. 3d 780, 788 (La. 2009).

12 See M.H. Hoeflich, The Lawyer as Pragmatic Reader: The History of Legal Common-Placing, 55 ARK. L. REV. 87, 88-89 (2002); D.W.M. Waters, Tribute to William F. Fratcher: The Role of the Trust Treatise in the 1990s, 59 Mo. L. REV. 121, 144-45 (1994). Some publishers marketed shorter editions of treatises to law students and law teachers who wanted to place the excerpted cases of a course book in larger context and to find answers to its relentless questions.

${ }^{13}$ Explanations of the important role of treatises in the legal research process remained quite consistent throughout the twentieth century. See, e.g., FrEDERICK C. HICKS, MATERIALS AND METHODS OF LEGAL Research: With Bibliographic Manual 154-59 (1923); Miles O. PriCE \& HarRy Bitner, EfFEctive Legal Research 266-67 (3d ed. 1969); Christina L. KunZ et Al., The Process Of Legal ResearCH 86 (4th ed. 1996).
} 
- Unlike annotations appended to statutes or headnotes attached to decisions, they organize the primary authority from the outside (not being captive of either the statutory structure or any particular judicial schema). That is not to say that effective treatises do not strive to make it easy for researchers working from a statute or a judicial opinion to enter the work at the pertinent spots. Typically they do so by means of highly explicit analytic structures and indices keyed to the specialized terminology of the field.

- Treatises synthesize the multiple strands of primary authority by identifying, summarizing, and analyzing the points of intersection among the principal statutory provisions, regulations, and judicial decisions.

- On issues to which numerous judicial opinions speak, good treatises highlight the better reasoned or more persuasive, enabling researchers, through the use of citators and other up-dating methods, to trace their influence.

- Where differences in treatment or application exist among jurisdictions, judicial circuits or departments, thorough treatises array them, providing references.

- When opinions on a topic are confused, hard to reconcile, or conflicting, treatises are expected, at a minimum, to identify the difficulty. Generally they go further to attempt a synthesis or provide the author's evaluation of competing approaches.

Finally, because law does not stand still, by the 1970s and 1980s most treatises had moved to a regular updating cycle. ${ }^{14}$ Whether by means of supplements designed to be slipped into the back of the original volumes, replacement pages that had to be inserted throughout loose-leaf binders, or periodic new editions, treatises were converted into ongoing information services. To the treatise user updates offered currency. For publishers and authors they provided a way to convert previously sold books into continuing sources of revenue. ${ }^{15}$

The traditional publication model in which the author traded ownership and dissemination control for a share of revenue provided the framework for assuring that treatises could be maintained over lengthy periods of time. In varying degrees the

\footnotetext{
${ }^{14}$ Writing in 1969, Raymond Taylor complained that not all publishers then followed this practice:

While it is customary for reputable lawbook publishers to provide for appropriate supplementation of their books, some publishers seem unmindful of the fact that this custom is the only reasonable way of justifying a high initial cost for a book or set that soon will become obsolete if not kept up-to-date for a reasonable period of time.
}

Raymond M. Taylor, Lawbook Consumers Need Protection, 55 A.B.A.J. 553, 555 (1969).

${ }^{15}$ Abuses in the sale of treatise updates were among the unfair trade practices which led the FTC to regulate the law publishing industry through a set of guidelines from 1975-2000. See 40 Fed. Reg. 33436 (Aug. 8, 1975), as corrected, 40 Fed. Reg 36116 (Aug. 19, 1975). See Raymond M. Taylor, New Protection for Lawbook Users, 61 A.B.A.J. 1373 (1975). By the 1980s and early 1990s, the prime consumer concern was not the absence or infrequence of supplementation but the soaring cost of keeping treatises up-to-date. Over the five years from 1987 to 1992, the publisher, Matthew Bender \& Co., more than trebled the annual cost of supplements to Moore's Federal Practice, raising it from $\$ 834$ to $\$ 2,693$. See KENDALL F. SVENGALIS, LEGAL INFORMATION BUyER's GUIDE \& REFERENCE MANUAL 11-16, 30-35 (1996). 
publisher's editorial staff might assist in the updating of a work even while the initial author or authors remained actively involved. Later, when the original author or authors lost the interest or ability to produce revisions or subsequent editions, the publisher had both the authority and incentive to bring in successors.

Despite being tightly connected to primary authority, treatises were produced and marketed independently. There was no need for a treatise publisher also to put out the statutes and decisions to which its publications referred. True, firms that marketed editions of primary authority did generally use their line of treatises to promote them in minor ways. A common practice was to express citations within a publisher's treatises in terms of the same company's editions of case reports or statutes. However, citation norms, which required, where necessary, the addition of parallel citations, allowed the purchaser of a treatise published by West Publishing Company to use it with statutes published by the Michie Co. or law reports published by Lawyers Cooperative Publishing. This "interoperability” enabled a large number of companies including Little, Brown \& Company, Warren, Gorham \& Lamont, and Matthew Bender \& Co. to publish highly successful treatises without having any involvement in the publication of primary authority. ${ }^{16}$

\section{Print Treatises and Online Primary Sources}

During the 1980s as the competition between Westlaw and Lexis became heated, the West Publishing Company saw opportunity for cross-platform synergy. It had a line of treatises. Mead Data Central, then the owner of Lexis, had none. ${ }^{17}$ West began inserting Westlaw references at the conclusion of treatise sections. ${ }^{18}$ Prepared by its editors, not the treatise author, these held out promise of breaking through two limitations of the print work. While the treatise author's citations might include few or no cases from the jurisdiction or circuit of particular concern to a researcher, these pre-formulated queries keyed into the relevant Westlaw database and appropriately modified could fill the gap. The added queries also dealt with a researcher's need for the most recent authority. Even with systematic supplementation, treatises lagged primary law developments by months, if not years. Use of embedded Westlaw references offered greater currency. By the mid1990s West had shifted from a section by section approach to treatise integration with Westlaw to the insertion of appendices that explained how Westlaw could be used to extend treatise coverage. $^{19}$

\footnotetext{
${ }^{16}$ These included, for example: Louis Loss, SECURITIES REgUlATION (1951) (Little, Brown \& Co.); BorIS I. BITTKER \& JAMES S. EUSTICE, FEDERAL INCOME TAXATION OF CORPORATIONS AND SHAREHOLDERS (3d ed. 1971) (Warren, Gorham \& Lamont); WiLliAM M. COLliER, COLLIER ON BANKRUPTCY (1940) (Matthew Bender).

${ }^{17}$ Mead Data Central's acquisition of the Michie Company, a major print publisher, in 1988 brought a number of treatises to its portfolio. The prime target, however, was Michie's catalog of primary material (state statutes). At that point both Westlaw and Lexis had announced their intention to provide comprehensive primary law coverage for all fifty states. See Peter W. Martin, Reconfiguring Law Reports and the Concept of Precedent for a Digital Age, 53 VilL. L. REV. 1, 20 (2008).

${ }^{18}$ See, e.g., Charles W. Wolfram, Modern LEgal Ethics 513 (1986).

${ }^{19}$ Compare 4 JAMEs J. White \& RoBert S. SumMERS, Uniform COMMERCIAL Code 477 (4th ed. 1995) with 2 JAMES J. White \& ROBERT S. SuMMERS, UNIFORM COMMERCIAL CODE 477 (3d ed. 1988).
} 
The 1990s also saw publishers experimenting with straightforward ports of individual treatises to CD-ROM. ${ }^{20}$ These were, as the current ebooks are, a bit like the earliest examples of the horseless carriage. While not designed for the medium, they offered distinct advantages over the original print form. Importantly, they enabled full-text search. Some of their references could be followed with a mouse-click. Copy and paste functions facilitated easy extraction of passages for insertion in notes or a brief. And to the extent the authors or publisher personnel took advantage of the medium's fluidity, electronic treatise editions could be kept dramatically more up to date. Nonetheless, these electronic works remained tightly conformed to the print original.

\section{Online Sources and Treatises Brought under Common Ownership}

Law publishers were able to insert pre-formulated queries and appendices tying treatises to their online services, to move treatises onto optical discs, later into their online systems, and eventually onto portable devices as ebooks because they held full copyright rights in them. Most treatises were initially prepared, updated, and periodically revised by individual authors - academics or practitioners expert in the field; but the standard publication agreement contained a full assignment of the author's copyright to the publisher. In return the publisher made a number of commitments including the promise to pay royalties.

Because publishers held copyright, as the law publishing industry consolidated in the final two decades of the twentieth century so did treatise ownership. The paths traced by the leading treatises on land use regulation illustrate these twin points and their consequences. During the mid-1960s Professor Robert M. Anderson of the University of Syracuse law faculty prepared a five volume work. He assigned copyright to the Lawyers Cooperative Publishing Company of Rochester, New York, and in 1968 it published the American Law of Zoning. Professor Anderson sustained the work through two subsequent editions. By the time the publisher was looking for a fourth, two things had happened. Anderson had retired from teaching and treatise-writing, and the publisher was no longer Lawyers Coop. The Thomson Corporation had acquired that company in 1989. Thomson subsequently transferred the Anderson treatise along with others to Clark Boardman Callaghan, a subsidiary it created in 1991 through the merger of two earlier acquisitions. Clark Boardman Callaghan assigned preparation of the fourth edition of the Anderson treatise to a member of its editorial staff. That edition appeared in 1995, not long before Thomson acquired the West Publishing Company. The West purchase led to further shifts in brand and editorial responsibility. A fifth edition of the work, one no longer carrying Anderson's name, appeared in 2008 in loose-leaf format under the imprint of Thomson/West (today simply Thomson Reuters). It was prepared by Professor Patricia E. Salkin of the Albany Law School. Salkin (now dean of Touro Law Center) also carries responsibility for the fourth edition of West's New York Zoning Law

\footnotetext{
${ }^{20}$ By 1995 Matthew Bender had issued most of its treatises in this format as an alternative to print. CCH offered several of its loose-leaf services on disc and West had produced a number of CD-ROMs combining commentary and primary authority in federal law fields. See KendALl F. SVEnGALIS, LEGAL INFORMATION BUYER’S GUIDE \& REFERENCE MANUAL 127-29 (1996).
} 
and Practice initially prepared by Robert Anderson and published by Lawyers Coop. ${ }^{21}$ Thomson's successive acquisitions brought numerous competing works into the company's treatise portfolio. They included Rathkopf's Law of Zoning and Planning (4th edition), which was for years updated and revised by Edward H. Zeigler and is now in the hands of Sara C. Bronin and Dwight Merriam. Rathkopf came into Thomson's ownership through its acquisition of Clark Boardman in 1980. A third treatise in the field, American Land Planning Law by Norman Williams, Jr. \& John M. Taylor, was acquired along with Callaghan \& Co in 1979. Thomson also owns and publishes works on the zoning law of several individual states. They include Connecticut, New Jersey, New York, Pennsylvania, and Ohio.

Reed Elsevier (which became owner of Lexis in 1994) achieved a zoning collection of its own through acquisitions of the Michie Company, publisher of zoning treatises by E.D. Yokley $^{22}$ and Daniel R. Mandelker, ${ }^{23}$ and Matthew Bender, publisher of both a single volume by Nyal A. Deems and N. Stevenson Jennette, III $^{24}$ and the massive Zoning and Land Use Controls by Patrick J. Rohan. ${ }^{25}$

Wolters Kluwer, too, assembled a large set of law titles through a series of publisher acquisitions in the 1990s - CCH in 1996, Little, Brown's medical and legal division in 1997, and Wiley Law Publications division in $1998 .^{26}$ The company's purchase of LoisLaw in $2002^{27}$ brought the resulting treatise catalog together with an online legal research service. Because of LoisLaw’s limited market share, Wolters Kluwer has also licensed treatise content to Westlaw.

BNA survived as an independent publisher of legal commentary until 2012 when Bloomberg Law, a relatively new player the online legal information market, purchased the company from its employee owners. ${ }^{28}$ The same year Bloomberg licensed exclusive online distribution rights to the Practising Law Institute treatise titles. ${ }^{29}$

\footnotetext{
${ }^{21}$ See Dean Salkin’s publications, http://works.bepress.com/patricia_salkin/ (last visited Aug. 17, 2015). Some of the recent updates have been prepared by a free-lancing attorney, Amy Lavine. See Amy M. Lavine, http://amymlavine.com/amy-m-lavine-zoning-and-land-use-law-attorney/ (last visited Aug. 17, 2015).

${ }^{22}$ E.C. Yokley, Zoning Law and Practice (4th ed. 1978-80) (8 volumes).

${ }^{23}$ Daniel R. Mandelker, Land Use Law (5th ed. 2003) (1 volume).

${ }^{24}$ Nyal A. Deems \& N. Stevenson Jennette, III, A Practical Guide to Winning Land Use Approvals and Permits (1990) (1 volume).

${ }^{25}$ Patrick J. Rohan, Zoning and Land Use Controls (1977-78) (10 volumes) (now overseen by Eric Damian Kelly who is described as the work's "general editor").

${ }^{26}$ Wolters Kluwer Timeline, http://www.ulib.niu.edu/publishers/Kluwer.htm (last visited Aug. 17, 2015).

${ }^{27} I d$.

${ }^{28}$ Bloomberg Completes Acquisition of BNA, Bloomberg Business, Sept. 30, 2011, http://www.bloomberg.com/news/articles/2011-09-30/bloomberg-completes-acquisition-of-bna.

${ }^{29}$ PLI Treatises \& Course Handbooks: No Longer Available through Law School License w/ Westlaw, Brooklaw Library Weblog, Nov. 12, 2012, http://brooklaw.wordpress.com/2012/11/12/pli-treatises-coursehandbooks-no-longer-available-through-law-school-license-w-westlaw/.
} 
In summary, U.S. law treatises have come to be owned by a handful of information conglomerates of global reach for whom online data services constitute the principal distribution channel and profit center, at least for their law holdings. The largest ones have acquired zoning treatises, copyright treatises, tax treatises, commercial law treatises, in duplicate and triplicate. Most of these works are now updated by second and third generation authors and editors, whose names may or may not be associated with the titles to which they contribute. In some cases they are respected academics or practitioners; in others, members of the publisher's editorial staff.

\section{Electronic Treatises and Online Primary Sources - Stage 1}

In the late 1980s, convinced that a treatise designed for use within (rather than apart from) the emerging virtual law libraries could provide levels of value only hinted at by digital conversions of existing print works, this author prepared and delivered papers with such titles as: "What a Computer-Based Legal Reference Work Can and Must Deliver."30 These reflections were prompted by and drew upon the effort to create such a work, a treatise covering the field of Social Security law liberated from the limitations of print and fully integrated with a supporting collection of primary authority.

The project not only led to investigation of what new forms of presentation and functionality were possible and desirable in this new legal information environment, but also provided (during the years running from 1988 through 1999) a bruising education in the shifting priorities and fortunes and consequent turbulence within the commercial legal information sector. Martin on Social Security debuted online in Lexis on June 1, 1991. The publication contract reflected the legal information vendor's plan for the work to serve as prototype for a future line of CD-ROM-based treatises. Both require a bit of context setting.

During the early 1990s neither Westlaw nor Lexis was a hospitable environment for an electronic treatise. Their content did not scroll. Neither system contained hyperlinks. Display was character-based. (It was not until 1998 that these competing systems moved to a fully scrollable, WYSIWYG, clickable Web browser interface.) ${ }^{31}$

\footnotetext{
${ }^{30}$ Peter W. Martin, What a Computer-Based Legal Reference Work Can and Must Deliver (May 1991), http://ssrn.com/abstract=2622632. See also Peter W. Martin, Design Requirements of a CD-ROM Based Reference System Capable of Replacing Print Materials in a Field of Law (Expert Systems in Law, Bologna, Italy - May 3-5, 1989), http://ssrn.com/abstract=2622558.

${ }^{31}$ See Peter W. Martin, Reconfiguring Law Reports and the Concept of Precedent for a Digital Age, 53 VILL. L. REV. 1, 21-22 (2008).
} 


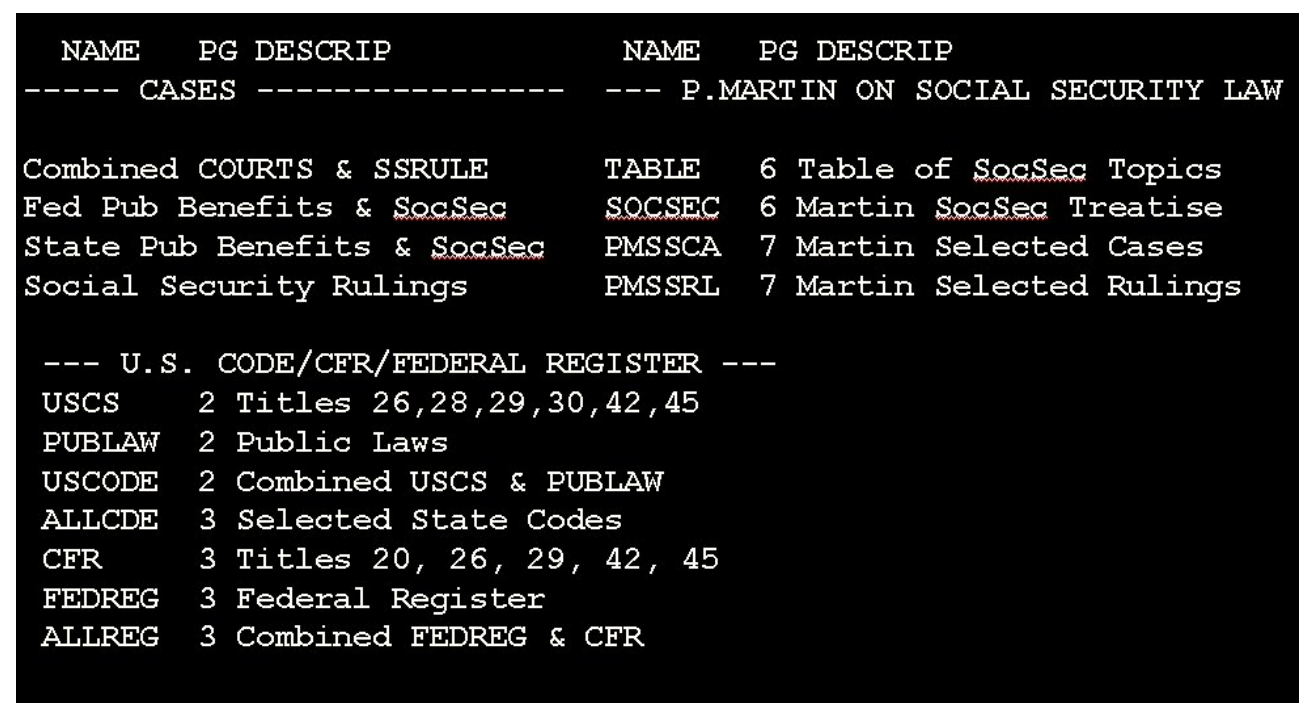

Figure 1. Martin on Social Security as it appeared on Lexis in 1991

A foundational principle, visible even in this crude first version of Martin on Social Security, is that a treatise designed for electronic delivery requires a tight relationship to a congruent, fully integrated primary law collection, statutes, regulations, judicial opinions, and - at least in this particular field - agency rulings. Yet to move from electronic treatise to primary authority in the online systems of the period required keying in a lengthy sequence of commands. These typed commands could be stacked but the resulting character string was typically long, ugly, and challenging to enter without error. To move from one section of this online treatise to the cases in Lexis dealing with its topic one had to type “.es;.df;PMSSCA;TOPIC(K100) and dom! or recognize”. Retrieving the pertinent subsection of the Social Security Act on the same point required keying "lxt 42 usc 416;.fo; h determination family status;.vk1;.fu." Issue by issue the treatise supplied the scripts necessary for such moves, but employing them was not easy. $^{32}$

Because of these and other limitations of the online environment of that era CD-ROM publication offered distinct advantages. The path was especially attractive as a means of delivering coherent collections that could be fit onto a single disc. At a time when most users connected to online systems through slow dial-up connections, having the data locally meant faster and more reliable response. Software available by 1990 allowed CDs to provide true hypertext, full-text search, and provided greater scope for structuring the data and therefore the user's interaction with it. In addition law CDs offered greater ease in printing and moving text from treatise, statute, or judicial opinion to research

\footnotetext{
${ }^{32}$ By 1990 Lexis had released a Windows-based client that made it possible for a user to block such long command strings and paste them, thereby removing the need to rekey. However, Windows penetration of the legal market was slow. Furthermore, because of the way this application parsed text it was not possible to block strings this complex with a click. The client software interpreted nearly all punctuation marks as word separators. Consequently, one had to bring the cursor from the beginning to the end of a command stack, with precision, to block it. A final point about this early Windows interface is that it did not expand the amount of text that a user could see. Until the late 1990s Lexis and Westlaw delivered text by the terminal screen-full, with each screen containing 80 characters across and 24 lines top to bottom, and some of that limited display real estate was occupied by navigation markers.
} 
notes, memorandum, or brief than the online systems. By 1993, the best offered a choice of WYSIWYG and character-based display.

Thomson's Clark Boardman Callaghan subsidiary released Social Security Plus on CDROM in 1994. While not the very first treatise to be issued in that medium, it was the first to be designed and written specifically for it. Critical to that initial product were the primary authority data available because of the contractual terms of the prior Lexis experiment. In addition to the core treatise the 1994 CD-ROM held well over 9,000 federal court decisions, the relevant statutes and regulations, agency rulings and manuals - all drawn from Lexis. ${ }^{33}$ That allowed it to offer levels of interactivity that were, until quite recently, simply not possible using standard Web technology to access content held by any of the online systems. By 1996 several other publishers of treatises and looseleaf services were offering CD-ROM versions either bundled with print or by separate subscription. ${ }^{34}$ With material as to which they had the choice, lawyers of the period preferred doing research on CD-ROMs to the online services. ${ }^{35}$

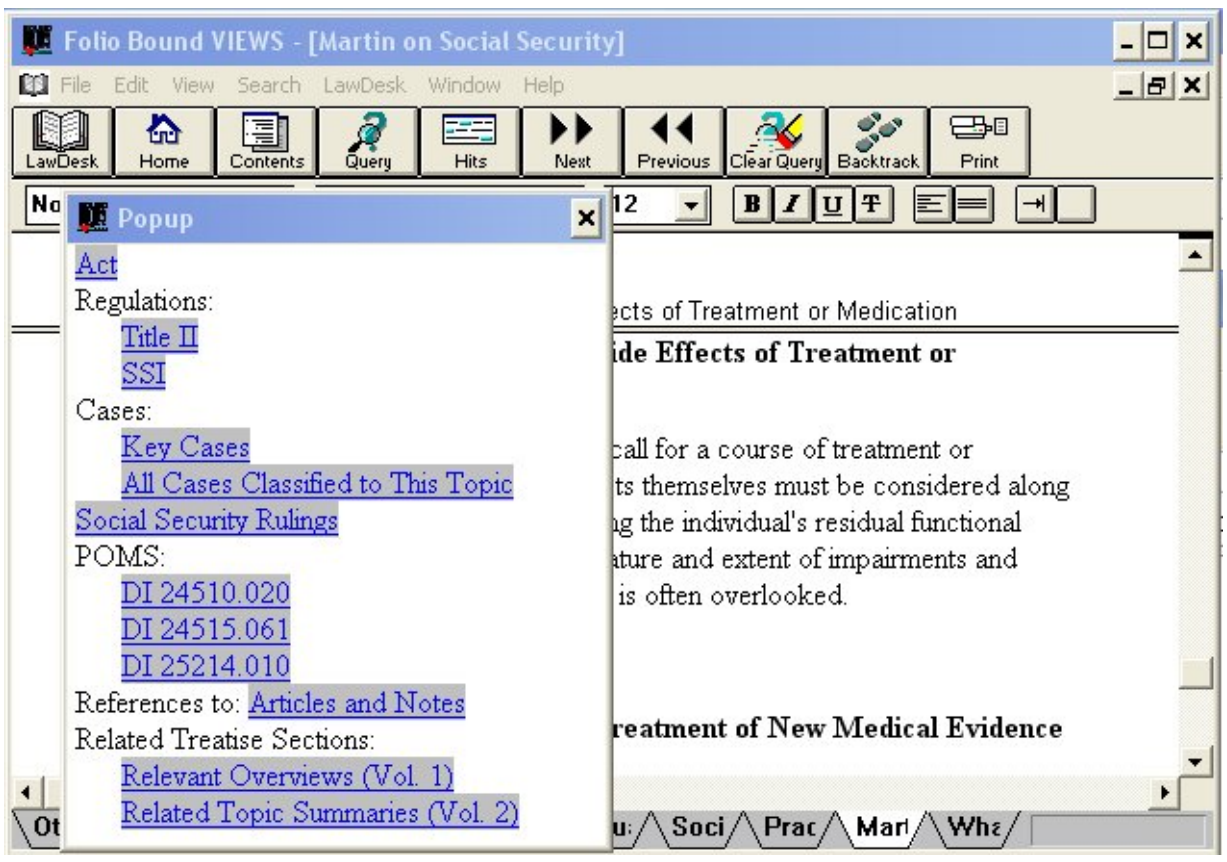

Figure 2. Martin on Social Security as it appeared on the Social Security Plus CDROM

Despite, or perhaps because of, the considerable market demand, there was no widespread exploration of what may have been the greatest advantage of the CD-ROM format, the opportunity it afforded to cut loose from the design constraints of print on the one side and the limitations inherent in large, decade's old mainframe data systems to create a new kind of specialized reference. Without a print original to which it had to

\footnotetext{
${ }^{33}$ By 1999 the case count was 12,480, and due to Thomson's acquisition of West the bulk of them were at that point drawn from Westlaw.

${ }^{34}$ See Kendall F. Svengalis, Legal Information BuyeR’s Guide \& REFERENCE MANUAL 127-129 (1996).

${ }^{35}$ See American Bar Association, 1999 Legal TeChNology Survey Report 71, 73 (2000).
} 
conform Social Security Plus was able to explore that space. Its design suggests some of the possibilities that, years later, remain largely untapped.

The introduction to this CD-ROM version of Martin on Social Security asserted that the central value of a reference work written for electronic use ought to reside in the links between its topical architecture and the supporting primary sources. It argued that the explanatory text written to accompany those links should focus on three principal goals: (1) providing context, (2) highlighting particularly important primary materials among the many accessible to the user, and (3) noting when relatively recent changes in law or regulation called for care when reading older decisions. Because the detailed provisions of the statute and regulations on any point were a click away, the work did not attempt to repeat their every qualification or condition. Its description of governing rules was at a more general level. On matters about which the researcher sought precise and authoritative information, she was instructed to follow the links to the pertinent sections of the statute and regulations, and other identified primary material.

A second major design difference dealt with the difficult spatial tradeoffs between exposition and citations that print treatises cannot escape. Where should the references to primary authority go? How much of a page should be given over to them? Taking advantage of the interactive possibilities of the medium, Martin on Social Security held all or most references out of the reader's path so that they did not intrude until the reader chose to pursue them.

Limited page real estate also forces difficult issues of comprehensiveness on a reference work, particularly on issues that are handled differently throughout the 50 states or the 13 regional circuits of the U.S. Courts of Appeals. Footnotes that go on for pages as they inventory authorities from all jurisdictions impose a very real burden on the reader. Yet the same reader will be frustrated by a list that omits authority from the jurisdiction of particular concern. Social Security Plus demonstrated that an electronic treatise linked to cases, rulings and other authority through topical metadata or other forms of linked search can give its users far richer possibilities - ranging from browsing through all cases on a particularly topic (arranged hierarchically by court) to pulling only those from a particular judicial circuit, to adding words or phrases to search within the set defined by author's treatise (e.g., all those on a point that involve epilepsy). 


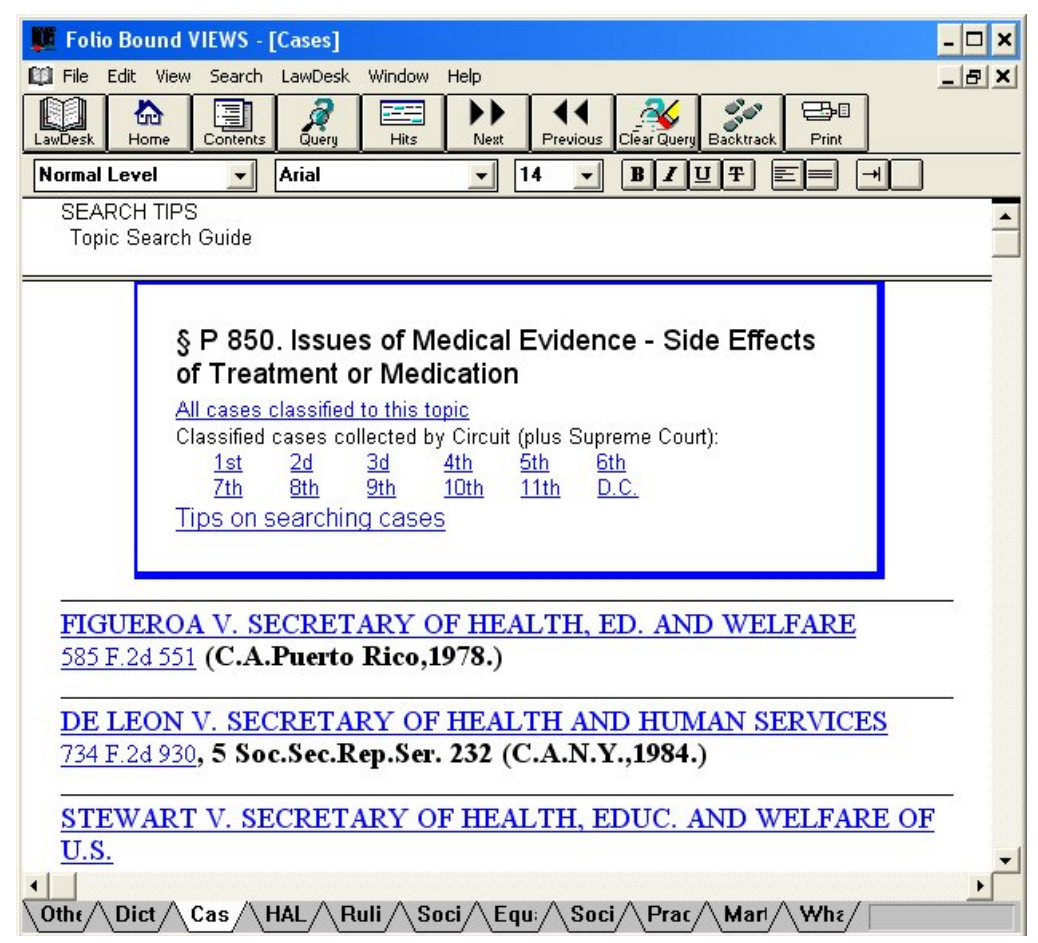

Figure 3. Multiple layers of point and click interactivity

Lastly a treatise prepared to do its work in an electronic environment need not be so linear or text bound as one written for print. Each section of the CD-ROM version of Martin on Social Security carried (out of the reader's field of vision until summoned) links to all other closely related sections. The work also contained interactive diagrams that guided users along a decision tree to the ultimately governing primary authority. Each branch of that tree offered those who were uncertain about the meaning of the operative terms a direct path to the regulation defining them. Commentary prepared for electronic delivery need not be limited to text. It can incorporate images, audio, and video.

\section{Electronic Treatises and Online Primary Sources - Stage 2}

Over the past decade and a half, advances in the Web technology available to the major legal research services, together with the widespread availability of high bandwidth Internet connections, have largely eliminated the technological advantages of having a treatise and its companion materials on disc. As a result CD- and DVD-based law publications have effectively disappeared from the market. ${ }^{36}$ By 2000 treatise content placed online as part of any of the major legal research services could be navigated through a graphical user interface. Programmatically inserted hyperlinks provided easyto-follow pathways from treatise citations to the referenced statute sections and case authority. Block and copy and print were only mouse-moves away.

\footnotetext{
${ }^{36}$ See KENDALl F. SVENGALIS, LEgAL INFORMATION BUYER’s GUIDE \& REFERENCE MANUAL 147-154 (2015).
} 
Until Lexis and Westlaw began to break down their rigidly compartmentalized data structures, however, a researcher had to know about a particular treatise, make her way to it and select it for search, to access its pertinent material. Citations to treatise provisions contained in judicial opinions did not provide a clickable path; they were not linked. It was only when the two major services began working toward their present global search paradigm, that discovery of relevant treatise content in the course of searching primary authority became possible. Initially, this was accomplished through a window showing commentary and other items of possible interest placed beside the search results drawn from the database targeted by the user. ${ }^{37}$ With today's latest generation systems searches are launched by default against a full range of database content, including treatises. As run on Westlaw Next, LexisAdvance, or Bloomberg Law, a search on "area variance" or "amortization of a nonconforming use" will retrieve commentary sources, including treatise sections drawn from works owned or licensed by the service provider, in addition to cases and statutes. And by default the selection among treatises and between treatise content and other sources of commentary such as journal articles and legal encyclopedias will be governed by the service’s ranking algorithm not the user.

Despite loading the treatises they own onto their comprehensive data services the major publishers still maintain and market the parent print editions. Indeed, it is possible that some few treatises with active authors still generate more revenue for publisher and author in print than in electronic format. Likely, little of that revenue is drawn from fresh customers. Those, however, who have long relied on the print version of a treatise are loath to let go. Among all types of legal research materials (case reports, statutes, journal articles, etc.), treatises and their like are, in fact, the most likely to be consulted in print rather than digital format. ${ }^{38}$ But "most likely to be consulted in print" should not be confused with "more likely than not." Since these are works for which one must continue to pay in order to receive updates and revisions, online use is likely to be more economic for the occasional user. For a firm or practice group it avoids the challenge of sharing one or more physical copies. Furthermore, there is strong evidence that lawyers, particularly those recently graduated from law school, prefer to do nearly all their research at a computer, including review of treatises and similar secondary materials. Recent ABA technology surveys reveal that over twice as many lawyers use an online source when researching a topic in a treatise or similar secondary reference as turn to print and that the gap between the two is widening. ${ }^{39}$ At least one major publisher is reinforcing that preference with financial incentive through steep increases in the price of treatise supplements. ${ }^{40}$

Recall that these are not works to be read through. They are consulted, episodically, as needed. In electronic form, full text search and hyperlinked navigation aids can

\footnotetext{
${ }^{37}$ On Westlaw this feature was called "Results Plus". Lexis had a comparable "Related Content" window.

${ }^{38}$ See 2013 ABA LEgAL TECHNOLOGy SURVEy Report V-31.

${ }^{39}$ See 2013 ABA Legal TeChNology SuRVEy RePORT V-xv (50.1\% versus 22.0\% for 2013 compared to 42.6\% and 29.1\% for 2010). See also Steven A. Lastres, Rebooting Legal Research in a Digital Age (2013), http://www.llrx.com/files/rebootinglegalresearch.pdf.

${ }^{40}$ That is the Svengalis report on Thomson Reuters. See KendaLL F. Svengalis, Legal INFORMATION BUYER's GUIDE \& REFERENCE MANUAL 36 (2015).
} 
dramatically speed access to the part or parts of a zoning treatise in point on any issue, such as the required amortization of a non-conforming use. Cross-references can be followed with a click. Once pertinent sections are found in an online work there is no need to leave one's desk or computer to read the cited authorities. Electronic publication also permits better integrated and more frequent updates.

To recapitulate, over the past three decades the rights to existing treatises have been gathered from the previous array of independent and competing publishers into large portfolios held by two conglomerates (three if one includes Walters Kluwer, the owner of Loislaw, Aspen Publishers, and $\mathrm{CCH},{ }^{41}$ four if one includes the most recent entrant, Bloomberg Law ${ }^{42}$ ). These companies have embedded the treatises they own within comprehensive subscription services. Online these commentary works have greater functionality but far less distinct visibility. And they are unavailable to non-subscribers. The value of a Thomson Reuters treatise online cannot be separated from its Westlaw context. Its Matthew Bender counterpart is available only as part of Lexis. And even for subscribers, depending on the terms of their contract, consultation of treatise content may trigger a substantial additional charge. If the title is not included in a subscriber's flat rate plan, accessing a single section may cost up to $\$ 80$. $^{43}$

In print treatises can be consulted without incurring incremental charges, they can be shared by multiple researchers, and they can be used with the full spectrum of online legal research services. These include the many smaller services in the U.S. (both free and fee) that have in recent years succeeded in securing respectable market or use share with collections of primary authority. While the likes of Fastcase, Casemaker, and Google Scholar don't have online commentary nor are they the targets of electronic treatise links, they can be used together with print treatises published by others.

\footnotetext{
${ }^{41}$ Wolters Kluwer's treatment of its treatise inventory is, at present, more mixed. Only a relatively small number of the company's legal titles are accessible through its LoisLaw service. Compare the full list at Wolters Kluwer Law \& Business, http://www.wklawbusiness.com/ (last visited Aug. 17, 2015), with those available on Loislaw, http://www.loislaw.com (last visited Aug. 17, 2015). Some of its strongest titles are bundled with appropriate primary law materials and offered online as specialist information services. See, e.g., Copyright Integrated Library, http://www.wklawbusiness.com/store/products/copyright-integratedlibrary-prod-000000000010032166 (last visited Aug. 17, 2015); Products Liability Integrated Library, http://www.wklawbusiness.com/store/products/products-liability-integrated-library-prod000000000010016234 (last visited Aug. 17, 2015).

${ }^{42}$ Bloomberg Law offers secondary sources alongside its primary law databases. These include a decade or so of law journals and treatises published by the Practising Law Institute (PLI) and BNA. See generally Robert J. Ambrogi, Can It Be a Contender? Bloomberg Law, 70 OR. ST. B. Bull. 15 (2010). Very recently the company launched a specialist service combining commentary and primary law material in the field of financial services law. See Bloomberg Law: Banking, http://www.bna.com/banking-law/ (last visited Aug. 17, 2015).

${ }^{43}$ See Lexis Advance Price Guide for Commercial Markets (June 25, 2015); WestlawNext, Pricing Guide for Commercial Plans (June 25, 2015).
} 


\section{Treatises in Ebook Format and Online Primary Sources}

The newly released ebooks might appear to offer the same benefit. Yet, unless one also subscribes to the publisher's online service, the target of an ebook's citation links, a major feature of the format is rendered valueless. Furthermore, it is not at all clear that in their present form and pricing they offer enough of an advantage over print on the one hand or over online access on the other to achieve significant market penetration. So far law publishers have rejected the Amazon pricing model; the current edition of American Law of Zoning costs the same in print and ebook form (\$896.00). For subscribers to the online service that already holds a treatise, the only advantages the new format offers are a fixed price and continued usefulness at times when network connections are unavailable. When accessible the online format provides substantially greater functionality.

To begin, the standard ebook applications are not designed for the type of use that law treatises normally receive. They have instead been optimized for sequential reading, for starting at the beginning of a work and paging through to the end. Ready access to a linked table of contents and the ability to bookmark and to search on individual words or exact phrases provide their only ways to break out of that linearity.

The navigation features standard with online treatises and the, now disappearing, disc publications are markedly superior. Those modes of digital publication remove the barriers resulting from the arbitrary division of printed text into volumes and pages. Readers are able to scroll as they examine an entire section, crossing page breaks with no loss of concentration. They can click through to content that, in print, resides in another volume.

With ebooks those print boundaries are back. The reader must choose a volume and then flip pages (sometimes back and forth if an important point is arbitrarily bisected). While ebooks accommodate cross-reference and footnote links, standard ereaders deliver the reader to a page, not a point. This is particularly problematic with footnotes. It means that when one touches or clicks on a footnote call one merely ends up on the page where the referenced note appears, having to remember whether it was note 34 or 37 that was the goal. In contrast, all of the major online services deliver the note to which a link has led at the top of the browser screen. One system goes further and highlights the note's background. Another system places footnote content in a popup window whenever the cursor hovers over the call. All major services enable immediate access throughout to tables of contents that position the current paragraph or section in context. These are not flat tables through which one must page, but scrollable, interactive ones. Chapter headings can be expanded to show subchapters, subchapters to show sections and so on. Far greater search capability and more useful display of search results also come with the online environment. ${ }^{44}$

\footnotetext{
${ }^{44}$ The Thomson Reuters ebook software, ProView, still a work in progress, does endeavor to address these shortcomings. In addition to providing reasonable boolean search capability, it places linked to material at the top of the screen and provides a table of contents that is both context sensitive and interactive.
} 
Treatises embedded in the major online services are at once enhanced and diminished by their surroundings. A researcher who does not know of a work or its value may discover it in a set of search results. Those results will place it next to related primary and secondary materials. Once within a treatise the reader may be furnished pathways to related material beyond the author's footnotes. The online versions of a number of the Thomson Reuters treatises now provide case law links that harness the West Key Number system and cross-reference links to discussion of the same topic in other treatises and practice guides held within the system. ${ }^{45}$ On the other hand, the merger of individual treatises into a vast ocean of content, alongside journal articles, practice guides, and directly competing works, ties their value ever more tightly to the database system of which they are a part. The individual work's distinct vantage point or analytic framework, even its quality and reputation, are inevitably submerged. Whatever their stature, all treatises sit on the same plain (or within the same results window) as student journal notes, ALR annotations, and legal encyclopedia entries. Indeed, they may fall below the others in the service's relevance ranking. ${ }^{46}$

Imagine, for a moment, an individual or a firm weighing which among major copyright treatises to acquire for ongoing use. The candidates would include Goldstein on Copyright, Nimmer on Copyright, and Patry on Copyright, published respectively by Wolters Kluwer, Matthew Bender (LexisNexis), and Thomson Reuters. All are available in print form, with regular updates, at a substantial subscription price. All three are also available online. In that (more useful) form the choice would be heavily, if not decisively, influenced, would it not, by the comprehensive database employed by the individual or firm for case law and statutory research. An IP lawyer who uses Westlaw would need a powerful attachment to the Nimmer treatise (far and away the most cited treatise of the three) to switch to Lexis, its online home or even to justify acquiring and maintaining it in print. Were LexisNexis to offer Nimmer as a stand-alone online product, as Wolters Kluwer offers Golstein on Copyright that might well supplant the print. Conceivably the publisher's hope for the ebook version is that it could do the same. At current pricing and functionality that seems unlikely.

\section{The Open Web as a Possible Environment for Legal Commentary of Scale and Longevity}

\section{A. The Necessary Primary Sources Are Now Accessible}

Until very recently a treatise had to reside within the same data space - i.e., on the same disc or within the same commercial database - as the primary law sources it analyzed to take full advantage of the digital environment. That is no longer true. The primary law materials to which most treatises refer (the pertinent statutory provisions, regulations, agency materials of other kinds, and decided cases) have moved to the open Web. No longer does an author or publisher preparing a treatise designed to access supporting

\footnotetext{
45 See, e.g., RAYMOND T. NimMER, LAW OF COMPUTER TECHNOLOGY §1:49 (WestlawNext).

${ }^{46}$ WestlawNext does offer a sort by citation frequency but since it treats the company’s encyclopedias as single titles they are ranked ahead of even the most cited treatise.
} 
authority by linked citation and search need to secure, reformat and update all the underlying sources as was necessary during the 1990s.

Concededly the Web's free legal materials lack the chronological depth and comprehensiveness of the major fee-based legal research services; however, those systems themselves have changed in ways that make it unnecessary for commentary to be located within their boundaries to connect directly to documents they hold. A text placed elsewhere on the Web can link to cases, regulations, statutes, law journal articles or other commentary on Bloomberg Law, Lexis, Loislaw, Westlaw, and most of their competitors. ${ }^{47}$ True, such links provide access only for subscribers to the target service, but it is possible for a work to give its readers a choice of source for cited and linked to material or to be issued in multiple versions.

Because a treatise or shorter work can link to all cited primary authority, as well as law journal articles and other secondary material, without being located behind the same fee barrier, such a work can be made available, with full value, to subscribers to any of the major online services. Indeed, because of the existence of open access legal databases, such a work can also deliver a high degree of value to individuals who subscribe to none of the commercial systems.

For the author or independent publisher, distribution of commentary on the open Web would appear to avoid having it buried deep in the pile of overlapping titles that the major online services have accumulated. The entities that own most U.S. legal treatises are, today, subject to incentives that seem quite at odds with the interests of individual authors.

Despite favorable conditions, enduring works of legal commentary designed for electronic delivery have not yet begun to appear in number on the Internet. Before that can occur, several issues, technical and institutional, have to be resolved.

\section{B. Missing Middleware and Data Structures}

Those who regularly work with commentary in digital format have been brought to expect a rich and intuitive set of navigation options, including full-text search. They assume that all explicit references to primary authority will be hyperlinked to the cited texts. If they are regular users of a particular online collection of primary materials, comfortable with its interface, familiar with its case citator and statutory annotations, and facile in pursuing fresh search trails from a relevant case or statutory section, they will carry a strong preference for online legal content that doesn't force them into a different research environment when they follow its links. These factors produce the first challenge to the placement of commentary works on the open Web. Binding a treatise through exclusive links to a particular collection of primary authority (Westlaw, say, or Bloomberg Law or even Google Scholar) dramatically reduces its usefulness to those who lack access to that collection or are simply habitual users of some other one. The publicly sponsored primary authority sites do not solve the problem. Although they represent an attractive option for some users, compared to the commercial services they

\footnotetext{
${ }^{47}$ All four of the named services have link formulas that will retrieve a cited document when elements of its conventional citation have been embedded in them.
} 
lack comprehensiveness. Moreover, they do not present a consistent interface, and, in far too many cases, do not enable retrieval using standard citation parameters. It is for good reason that legal professionals who can turn to one of the commercial services that gather, organize, and add value to public law documents.

A partial solution lies in links that provide the user with a choice of source. Limited examples already exist. Because most of the commercial legal information services respond to links derived from standard citations or pre-formulated queries and because general purpose Internet search engines will, in similar fashion, retrieve legal documents from free sites that are open to them this approach offers promise.

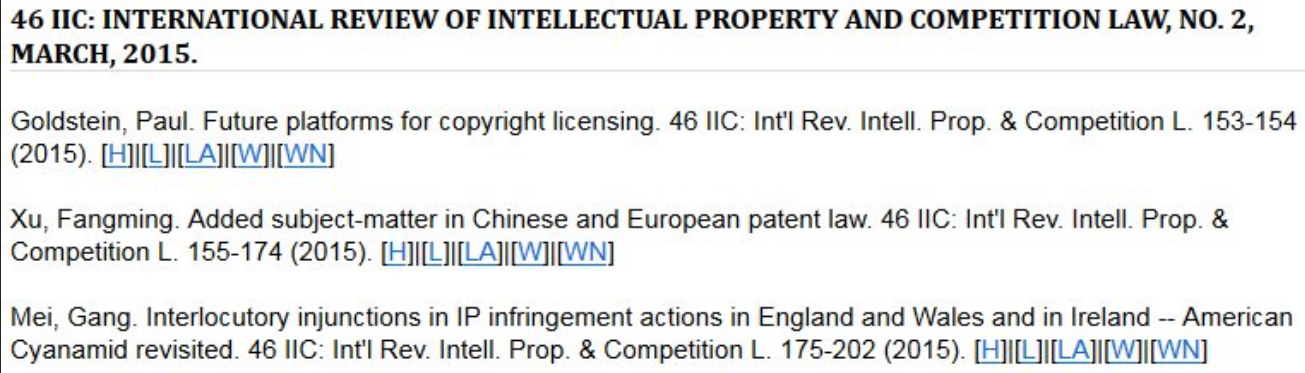

Figure 4. Choice of source law journal links in SmartCILP published by the M.G. Gallagher Library, University of Washington

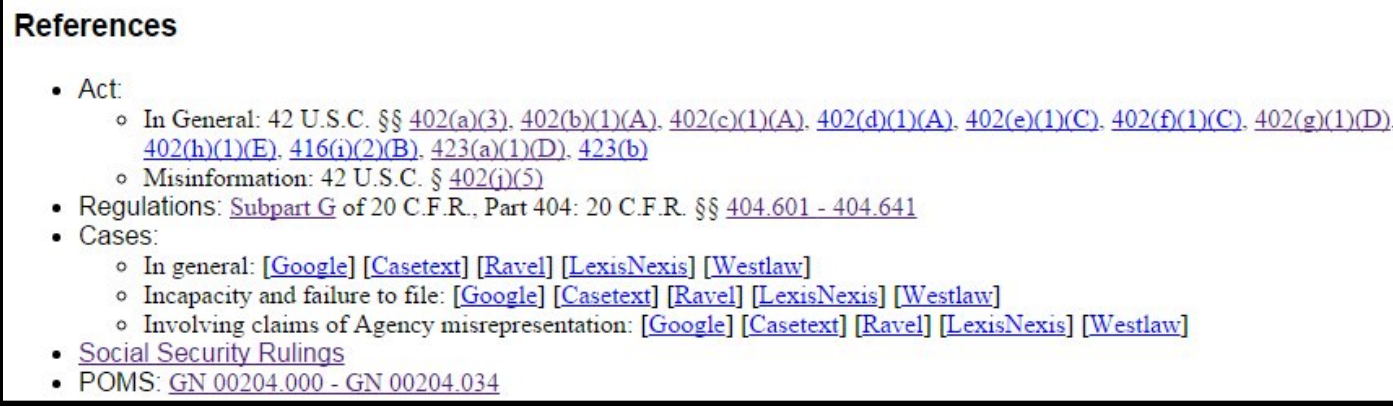

Figure 5. Choice of source case law links in an experimental version of Martin on Social Security

The technology required to generate "multiple choice" links is straightforward. They can even be produced on the fly. It would not be difficult to create a "citation link server" capable of receiving a link request delivered in a specified format and redirecting it to the legal database or law site of the researcher's choice.

A second form of integration suggested by the CD-ROM version of the Social Security treatise described earlier would require a more complicated data and search utility, one capable of associating topical tags with large sets of primary law documents. Going beyond static links between commentary text and individually cited authorities, the concept here is of a set of data tags that identify a population of primary law documents as lying within the scope of the commentary work and even go further, subdividing them along issue, topical, and jurisdictional lines. Such tags would, in a way, be analogous to 
the Thomson Reuters Key Number topic structure, the Lexis headnote topic hierarchy, or the topic categories of Bloomberg Law, but both organization and granularity would be tied to a specific treatise. Like the treatise itself, these would have to reside outside the individual information services relied on for primary authority. A case identified by an author as within the scope of a treatise and pertinent to one or more of its topics would for this purpose be specified by citation and tagged appropriately. By searching on the author-assigned tags a researcher working from the treatise would be able to retrieve all cases bearing on a particular point, simply by following a link. Ideally, all tagged cases associated with a treatise would also be indexed in full text so that those following a query link based on the author's tags could further refine the search. The software and database tools of which such a system might be constructed exist, but working examples in the field of law are few. ${ }^{48}$

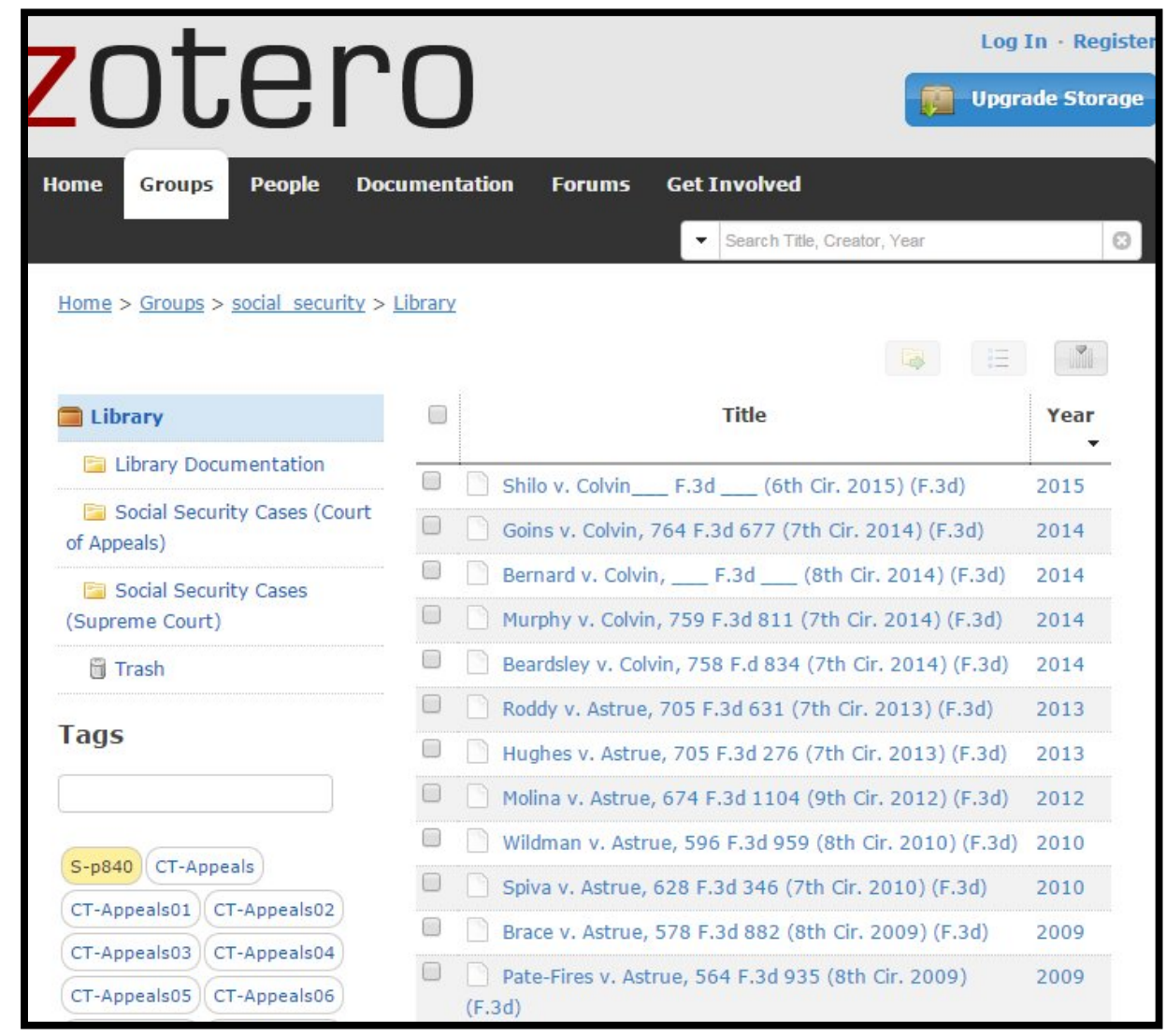

\section{Figure 6. Cases discussing the issue addressed in § P 840 of Martin on Social Security}

\footnotetext{
${ }^{48}$ There are a number of resource tagging tools on the Web. Among them are Delicious, http://www.delicious.com and CiteULike, http://www.citeulike.org. It is, however, the capability of the Zotero software to share tags that the author has found most adaptable to cited legal materials. See Zotero Groups, http://www.zotero.org/groups/. For an implementation tagging over 4500 Social Security decisions, see Zotero, http://www.zotero.org/groups/social_security/items.
} 


\section{A Need for New Kinds of Publishers or Hosts}

If a public-interest organization or commercial entity were to create the linking and tagging utilities described above would authors and publishers come? Without enthusiastic sponsorship combined with advocacy for and guidance on use of those integration tools together with some conspicuous prototypes, it seems very unlikely that individual authors would discover and use them. Assuming clear theoretical advantages of an independent presence on the Web over inclusion in the holdings and database of any of the major legal information providers, authors must still be persuaded of those advantages and helped to pursue them.

Writing over two decades ago, Henry Perritt argued that the theoretical advantages of electronic publication would not prevail over print so long as print publishers continued to offer more of the "types of value" historically bundled together with book publishing. ${ }^{49}$ Perritt's inventory of those "types of value” included quality assurance (both at the time of author selection and subsequently), support and assistance to authors in the preparation, organization, and maintenance of their works (on matters ranging from format and index preparation to updating), production, promotion, distribution, and sales. ${ }^{50}$ As noted previously, with enduring law treatises, publishers have also assured maintenance over time, even to the point of bringing in collaborating and successor authors as needed. These multiple forms of value, commonly bundled in or lying back of books, have been shaped by significant needs of authors and information product consumers. Perritt's thesis was that while electronic media make it possible for "traditional information supplier functions to be disintegrated and performed by multiple suppliers in the place of single authors or publishers or combined in different ways," the need for someone to perform them remains. ${ }^{51}$

To date, no clear examples of institutional arrangements that offer comparable levels of value to potential authors of electronic legal commentary and consumers of such works have emerged. Yet suggestive possibilities do abound. Some of these involve existing organizations taking advantage of opportunities opened by electronic media and the Web. Others consist of efforts to adapt novel forms of intellectual production and distribution that have emerged on the Web to the domain historically served by the law treatise. A few examples follow.

\section{Existing Institutions Becoming Publishers of Significant Online Commentary}

Some law firms have become serious Web publishers, offering their clients ${ }^{52}$ and potential clients ${ }^{53}$ online or email-delivered newsletters and exposition of the law on

\footnotetext{
49 See Henry H. Perritt, Jr., A Value-Added Framework for Analyzing Electronic and Print Publishing, 1 INTERNET RESEARCH 18 (1991)

${ }^{50}$ See id.

51 See id. at 21.

52 See, e.g., Foley \& Lardner LLP - Intelligence, http://www.foley.com/intelligence (last visited Aug. 17, 2015).
} 
specific topics. In most instances, however, these works are not designed to be a starting point for additional research or reference works for legal professionals. ${ }^{54}$ Consequently links to primary authority are rare. Organizations with distinctive issue-defined missions, legal information institutes, and other non-governmental organizations, even public bodies focused on particular fields, are also potential online publishers of expert commentary. The Sargent Shriver National Center on Poverty law, which supports the work of lawyers serving indigent clients, has taken a print treatise and moved it to the Web with links to cited authority. ${ }^{55}$ The U.S. Court of Appeals for the Seventh Circuit maintains its Practitioner's Handbook, containing detailed commentary on federal appellate practice, richly supported by citations to primary authority, online. ${ }^{56}$ For a time it was structured as a wiki. ${ }^{57}$

\section{New Forms of Production and Dissemination - Blogs, Wikis and ...}

\section{a. Law Blogs}

The "blog" is a versatile genre. Within the field of law blogs have been used to complement works of treatise-like scope and duration, but not to supplant them. Numerous treatise authors have or have had a blog. Charles Hall, author of Social Security Disability Practice ${ }^{58}$ and lead attorney for a law firm engaged in that line of representation, writes a "Social Security News" blog. ${ }^{59}$ Patricia Salkin, author of several land use books, including the American Law of Zoning, ${ }^{60}$ blogs on land use law and zoning. ${ }^{61}$ For several years William Patry, author of a multi-volume copyright treatise, ${ }^{62}$ maintained a highly regarded blog in that field. ${ }^{63}$ All three illustrate ways in which a blog can be a natural extension of a treatise author's ongoing need to track and analyze fresh legal developments within its scope. They also demonstrate how a blog can be used to display the author's expertise and give greater visibility to the published work itself.

\footnotetext{
53 See, e.g., Immigration Lawyer, Guide to U.S. Immigration Law, http://www.visalaw.com/ (last visited Aug. 17, 2015); The Charles T. Hall Law Firm, http://www.charleshallfirm.com/ (Social Security Disability Law) (last visited Aug. 17, 2015).

54 There are exceptions. The Web site of one highly regarded Social Security attorney is exclusively devoted to case references and other materials relied on by others practicing in the field. See schnaufer.com, http:// www.schnaufer.com (last visited Aug. 17, 2015). See also Martin and Jones, Articles for Attorneys, http://www.theatlantadisabilitylawyer.com/articles-for-attorneys/ (last visited Aug. 17, 2015).

55 See Federal PRACTICE MANUAL FOR LEGAL Aid ATTORneys (2014), http://federalpracticemanual.org/.

56 See PRACTITIONER's HANDBOOK (2014), http://www.ca7.uscourts.gov/Rules/handbook.pdf.

${ }^{57}$ See infra p. 24.

${ }^{58}$ Charles T. HALl, Social SECURITY DisABility PRACTiCE (2015).

${ }^{59}$ Social Security News, http://socsecnews.blogspot.com/ (last visited Aug. 17, 2015)..

${ }^{60}$ See supra p. 7.

${ }^{61}$ Law of the Land, http://lawoftheland.wordpress.com/ (last visited Aug. 17, 2015)..

${ }^{62}$ WiLliam F. PATRY, PATRY ON COPYRIGHT (2015).

63 The Patry Copyright Blog, http://williampatry.blogspot.com/ (last visited Aug. 17, 2015)..
} 
Charles Hall's blog includes links to an order form for his book and also to his firm's site. $^{64}$

The inherent structure of a blog is chronological. It is therefore well suited to updating and current awareness. While postings on specific topics inevitably accumulate over time, ${ }^{65}$ neither the nature of the software environment nor the expectations of those visiting such a site encourage potential authors to see the blog format as congenial for constructing and sustaining a treatise-length work. When William Patry ended his blog in 2008, he was confronted with strong user demand that it be archived. In the end, he yielded $^{66}$ but only after explaining that despite the care that he put into writing its entries he "regarded them as ephemera." 67

\section{b. Wikis}

A more likely electronic framework for handling some of the functions addressed by the traditional book publishing model is the "wiki” approach to collaborative authoring. Its content structure enables topical organization accompanied by limitless cross-linkages. Collaboration, including, importantly, collaboration over time (ongoing revision, elaboration, updating) is key to the concept, as reflected in its best known implementation, Wikipedia. ${ }^{68}$ Wikipedia itself contains a substantial amount of legal commentary. ${ }^{69}$ The companion textbook project (Wikibooks) contains a law category; but so far it contains comparatively little U.S. content. ${ }^{70}$ A few non-profits (including Cornell's Legal Information Institute ${ }^{71}$ and the Michigan Poverty Law Program ${ }^{72}$ ) sponsor openly accessible and editable law wikis. At least one law practice community tried to sustain a wiki as a way to organize, hold, and share member expertise, limiting both access and editorial privileges to members of the group. ${ }^{73}$ Within law firms the wiki

\footnotetext{
${ }^{64}$ See Social Security News, http://socsecnews.blogspot.com/ (last visited Aug. 17, 2015)..

${ }^{65}$ Some, but by no means all, blogging platforms allow an author or moderator to tag postings so that users can retrieve all those dealing with a particular topic. See, e.g., Law of the Land, http://lawoftheland.wordpress.com/ (last visited Aug. 17, 2015).; The NAFCU Compliance Blog: Archives, http://nafcucomplianceblog.typepad.com/nafcu_weblog/archives.html (last visited Aug. 17, 2015)..

${ }^{66}$ Restoring Old Posts, The Patry Copyright Blog (Aug. 8, 2008), http://williampatry.blogspot.com/2008/08/restoring-old-posts.html.

${ }^{67}$ Archiving the Blog, The Patry Copyright Blog (Aug. 6, 2008), http://williampatry.blogspot.com/2008/08/archiving-blog.html.

${ }^{68}$ Wikipedia, http://www.wikipedia.org/ (last visited Aug. 17, 2015)..

${ }^{69}$ See Wikipedia: WikiProject: Law, http://en.wikipedia.org/wiki/Wikipedia:WikiProject_Law. For a number of years the Practitioner's Handbook, at the Seventh Circuit site was structured as a wiki. See Trial Ad (and Other) Notes (May 12, 2007), http://rialadnotes.blogspot.com/2007/05/seventh-circuit-wiki.html.

${ }^{70}$ See Subject: Law - Wikibooks, open books for an open world, http://en.wikibooks.org/wiki/Law (last visited Aug. 17, 2015)..

${ }^{71}$ See Wex, http://topics.law.cornell.edu/wex/ (last visited Aug. 17, 2015).

${ }^{72}$ See Michigan Reentry Law wiki, http://reentry.mplp.org/ (last visited Aug. 17, 2015).

${ }^{73}$ This wiki was limited to participants in a listserv whose members represent individuals pursuing Social Security claims. See ssl- Social Security law for non-government lawyers, http://sympa.theombudsman.com/sympa/info/ssl (last visited Aug. 17, 2015).
} 
structure has been adapted to sharing knowledge and information among members of work groups and across offices. ${ }^{74}$ The Sargent Shriver National Center on Poverty Law has created a wiki containing "resources of interest to the new legal aid lawyer," at least one of them being the Poverty Law Manual for the New Lawyer, previously published in print. $^{75}$ Yet, to date, the wiki framework has not proven, in and of itself, to be the answer to treatise construction and maintenance. As the Seventh Circuit discovered with its Practitioner's Handbook, converting an existing print work to a wiki, together with an invitation to any and all users to improve and update its content, can lead to discouraging results. $^{76}$

Lawrence Lessig's Remix identifies several features shared by successful and sustainable Internet ventures built upon collaborative or community production of content (and also approaches that appear not to work). ${ }^{77}$ Drawing on such examples as Flikr, YouTube, SlashDot, and Yahoo! Answers, Lessig argues that it is important to give contributors something they need, combined with a sense of ownership or responsibility. Simple calls for volunteerism are not enough. Ideally, users contribute value as a by-product of getting something that they need. ${ }^{78}$ What they need may include sharing, helping, or showing their expertise. ${ }^{79}$ Overt commercialism can be a deterrent, and terms and conditions that appropriate ownership and control of all contributions to the site will almost surely be one. ${ }^{80}$ So far the sweet spot for collaborative production or maintenance of large scale legal commentary on the Net has not been discovered.

\section{c. An Opening for New Publishers and Other Novel Web Structures?}

One recent Web venture, Spindle Law, tried a more radical break with the institutional and structural features of the conventional law treatise. ${ }^{81}$ Spindle Law’s ambition was to

\footnotetext{
${ }^{74}$ See,e.g., David Hobbie, Technology: Legal Web 2.0: Personal Knowledge Management, 36 ABA, Law Practice, March-April 2010, at 26.

${ }^{75}$ See Poverty Law Resources for the New Legal Aid Lawyer, http://povertylaw.pbworks.com/.

${ }^{76}$ An Internet law treatise, hosted by the Electronic Frontier Foundation (EFF), provides another example. With the ambition of providing a "collaborative treatise summarizing the law related to the Internet with the cooperation of a wide variety of attorneys, law students and others” the EFF placed a guide originally published in 2003 on the Internet in wiki format. Years later it remains in "beta". The last changes appear to have been made over five years ago. See InTERNET LAW TREATISE, http://ilt.eff.org/index.php/Table_of_Contents (last visited Aug. 17, 2015).

77 See LAWrence Lessig, Remix: MAKING ART AND COMMERCE THRIVE IN THE HYBrid ECONOMY 186213 (2008). On incentives and cooperative value production see also YOCHAI BENKLER, THE WEALTH OF NeTWORKS (2006); YOCHAi BENKLER, THE PENGUIN AND THE LEVIATHAN (2011).

${ }^{78}$ See id. at $186-96$.

${ }^{79}$ See id. at 196-213.

${ }^{80}$ See id. at 243-248.

${ }^{81}$ Spindle Law, http://spindlelaw.com/start (no longer online). For contemporaneous descriptions of the site, see Laura Bergus, Legal Research Gets Innovative with Spindle Law (July 13, 2010), https://lawyerist.com/11818/legal-research-spindle-law/, Robert Ambrogi, New Site Crowdsources the Legal Treatise (July 12, 2010), http://www.lawsitesblog.com/2010/07/new-site-crowdsources-the-legaltreatise.html.
} 
cover the principal practice areas of U.S. law with commentary supported by references to primary authority. This was to be no simple port of the print treatise model to electronic media, but, according to the site, "a new kind of legal research and writing system.” Like a wiki, Spindle Law invited all registered users to add to its content, articulating propositions of law on a specific point ('rules" or “exceptions”), adding, editing, or vouching for authorities in support of a point, and inserting comments. The topical architecture and editorial oversight within a branch of law were to be provided by Spindle-designated editors, termed 'branch managers.' Navigation was highly interactive. Search was controlled by topical structure. An extensive set of icons were available to signal case outcome and court and the nature of a legal proposition (e.g., topic, rule, rule with exceptions, exception to a rule). Cited authorities were linked to the full text at multiple sites, both free (e.g., Google Scholar, the Public Library of Law) and some that charge a fee (Lexis, Westlaw, Fastcase). A utility facilitated the exportation of both text and citations to a user's research notes. Tellingly, Spindle Law failed to generate sufficient authorial involvement across the fields of law to attract a substantial user base. After a short span of time it disappeared.

A more recent startup, Casetext, ${ }^{82}$ has also pursued a crowd-sourcing model of commentary production. It is far too soon to see whether its combination of distinct communities of interest ${ }^{83}$ and helpful authoring tools ${ }^{84}$ will enjoy greater success than Spindle and whether, if successful, it will break out of the scope and temporal limitations inherent in the blogging genre.

\section{Concluding Reflections}

U.S. law treatise publication has consolidated in a handful of firms. Their incentives all point toward integration of commentary material of all sorts into their respective comprehensive, subscription-based information systems. Locating a treatise on the Web outside those systems could well offer would be authors, individually or in large-scale collaborations, a broader audience particularly if that placement did not deny users the features of their favorite comprehensive source whenever they followed one of its links to a cited case, statute, or journal article.

What are the odds that authors will respond and create treatises or successor forms of quality legal commentary on the open Web? The answer lies ultimately not in the existence of a congenial information environment (It already exists.) or appropriate information management tools and Web utilities (They are not difficult to conceive or build.), but rather on whether entities emerge that are able to recognize the opportunity and to create the institutional supports and incentives necessary to draw legal authors into a new form of sharing individual and collective expertise.

The dominant commercial legal information services, having accumulated vast quantities of commentary through merger and acquisition, commentary to which they hold copyright and which they pay to sustain, are not likely to permit any of those assets to

\footnotetext{
${ }^{82}$ Casetext, http://www.casetext.com (last visited Aug. 17, 2015).

83 See Communities, http://casetext.com/communities/ (last visited Aug. 17, 2015).

${ }^{84}$ See Jake Heller, Introducing LegalPad (June 18, 2015), http://casetext.com/posts/introducing-legal-pad.
} 
escape to the open Web or be linked to primary law collections other than their own. They are also in a position to offer financial incentives to freelance writers and to deploy their own editorial personnel to create fresh content in legal fields not yet adequately covered. Unquestionably, they have the capability to build or commission or reconfigure existing legal treatises in ways that break free from print constraints and are available apart from their comprehensive online libraries. But the brief history of the Internet strongly suggests that innovation is more likely to arise from other sources.

Putting out existing treatises in ebook form represents a clumsy attempt to map legal commentary publication onto the explosive growth in electronic distribution of other forms of book-length writing. Without far more sophisticated software, reconfiguration of content to fit this very different environment, altogether different pricing strategies, or a combination of all three it is not likely to change how lawyers, judges, and other professionals work with this kind of material.

It does seem probable that the fresh potential of the Web, including the possibilities it opens for collaborative authorship and novel forms of presentation, will ultimately draw a new set of commentary publishers or hosts. Some may want their offerings to reside on the open Web, available without charge to all who would find and use them. Others will explore the fresh possibilities for sharing expertise and information within an organization or practice community. Still others may pursue commercial opportunities through small scale electronic publication of legal commentary. For treatises truly to bloom in this new environment, their sponsors, hosts, or publishers will have to find an effective mix of incentives to induce individual expert authors (academics, experienced practitioners) to undertake and later sustain large works of authorship, a credible framework for building a coherent and reliable work out of voluntary contributions by many, or some combination of the two.

What enticements might lead the expert lawyer or the academic specialist to prefer to publish on the open Web? One possible answer is full personal control - retention of copyright and all that makes possible. At the other extreme, the collaboration possibilities on the open Web may draw authors who would never imagine undertaking a full treatise on their own. Where personal financial return fits is a puzzle. More than a few legal academics of my generation bought second homes and financed their children's college education with royalties from commercially published commentary works. If their treatise was a success, and the field, active, those works continued to generate revenue and consequently royalties through annual or semi-annual updates. Author returns on that scale seem unlikely to continue in the digital environment. However, the prospect of royalties alone cannot explain the authorial effort expended on most legal scholarship. Undoubtedly, a powerful motivator for the production of works of this sort has always been the desire to share and show one's knowledge, to have professional impact, to gain recognition. There are by now countless examples that demonstrate how placing valuable content on the open Web can expand the audience for it. For some potential treatise authors, perhaps a significant number, that may provide the most powerful inducement. 